University of Nebraska - Lincoln

DigitalCommons@University of Nebraska - Lincoln

Faculty Publications: Agricultural Leadership,

Agricultural Leadership, Education \& Education \& Communication Department

Communication Department

April 1992

\title{
Deterrents to Female Enrollment in Secondary Agricultural Education Programs in Nebraska
}

Lloyd C. Bell

University of Nebraska - Lincoln, Ibell1@unl.edu

Susan Fritz

University of Nebraska - Lincoln, sfritz1@unl.edu

Follow this and additional works at: https://digitalcommons.unl.edu/aglecfacpub

Part of the Other Public Affairs, Public Policy and Public Administration Commons

Bell, Lloyd C. and Fritz, Susan, "Deterrents to Female Enrollment in Secondary Agricultural Education Programs in Nebraska" (1992). Faculty Publications: Agricultural Leadership, Education \& Communication Department. 8.

https://digitalcommons.unl.edu/aglecfacpub/8

This Article is brought to you for free and open access by the Agricultural Leadership, Education \& Communication Department at DigitalCommons@University of Nebraska - Lincoln. It has been accepted for inclusion in Faculty Publications: Agricultural Leadership, Education \& Communication Department by an authorized administrator of DigitalCommons@University of Nebraska - Lincoln. 


\title{
Deterrents to Female Enrollment in Secondary Agricultural Education Programs in Nebraska
}

\author{
Lloyd C. Bell, Assistant Professor \\ Susan M. Fritz, Doctoral Candidate \\ University of Nebraska-Lincoln
}

"Scientific and professional expertise in the food and agricultural sciences is a national resource critical to the continuing security of this Nation." This renewable resource, however, is being depleted by an annual employment shortfall of ten percent. Approximately 4000 employment opportunities go unfilled because of too few new college graduates with expertise in agriculture, natural resources, veterinary medicine, and closely aligned fields (Coulter, 1986).

Students usually equate a career in agriculture with farming or ranching only, rather than with the science or business of agriculture which leads to a pervasively negative opinion of pursuing a career in agriculture (Orthel, Sorensen, Lierman and Riesenberg, 1989). In fact, Krueger and Riesenberg found that secondary students perceived an agricultural career to be boring, hard work with poor pay, and involving more muscle than brain. They Perceived an agricultural career as an outdoor job that involves more men than women (1991). In the same research a factor found to be related to student perception of agricultural careers was secondary education in agriculture. Students with some background in high school agriculture seemed to be more interested in pursuing an agricultural career than students without a background in agriculture. Fifty-six percent of the students who had participated in secondary agricultural education had considered a career in agriculture, while only 18.5 percent of the students who had not participated had considered such a career choice.

"White males have mainly made up enrollment in vocational agriculture programs in the past and continue to do so. During the past decade, the enrollment of females has increased. Female enrollment has concentrated in a limited number of specialized vocational agriculture programs. Enrollment of minorities in vocational agriculture is disproportionately low." The preceding statements were principle findings in the National Academy of Science Agricultural Education report, Understanding AgricultureNew Directions for Education (1988).

Since participation in secondary agricultural education does affect student attitude toward the consideration of agricultural careers, it may be assumed that the numbers of "traditional" enrollees will not significantly increase to fill the current employment shortfall, and that a portion of the supply will need to be "nontraditional" enrollees. (Nontraditional enrollees being defined as either currently unrepresented or under represented.) In terms of gender, a nontraditional vocational education program is defined in the literature as having either gender represented at 20 percent or less of the total enrollment (Sproles, 1986). The challenge then becomes how to gain the interest of nontraditional students in secondary agricultural education.

Females offer a critical difference to the employment matrix beyond just a partial remedy to the short fall of numbers. For the most part, females are culturally socialized to build and maintain relationships through cooperation, while males are socialized in a hierarchical world focused in status and competition (Tannen, 1991). The leadership model in business and industry for the 90's emphasizes affiliation and nets of connectedness (Heifetz, 1991). Change is/will be a result of networking and communicating. Characteristics that were once termed as "feminine" have found their place in business and industry leadership and success. 
The question of representation by nontraditional "players" in a profession is a subjective one. Nationally, in 1980, women comprised 11 percent of the students in traditionally male vocational programs. (Giese, 1980). In 1989 the percentage had grown to 13 percent. Efforts by Wider Opportunities for Women (WOW) to define the meaning of this growth pattern found that in both secondary and post-secondary schools, a mirror image existed of the occupational segregation in the current labor force. "Female students are in secretarial, cosmetology, food service, and health occupations classes, and male students are in the skilled trades and technical classes. Even in computer classes, which showed a more even distribution of male and female students, males were pursuing programming and analysis while females were pursuing word processing" (Beck, 1989).

Lillydahl (1986) had previously addressed this gender appropriate segregation phenomenon through economic theory focusing on demand side factors affecting female entry into the job market. All of the demand side theories (discrimination theory, theory of statistical discrimination, crowding theory, internal labor market theory) build from a subtle premise that females are not first consideration applicants for nontraditional employment opportunities. In contrast, considering the supply side of economic theory, women accepting the demand premise of not being a first consideration applicant choose the more traditional employment opportunities. The perpetuation of the demand side theories contribute to occupational crowding and lower relative wages. The demand theory is embedded in cultural bias; the supply theory is a phenomenon of acceptance.

Research has shown the greatest influence on anyone's career decisions is the mother. However, the institution that exerts an equally strong influence, from early childhood through at least age 16, is the school (Beck, 1989). In consideration of a nontraditional educational or career decision, what are the obstacles female students encounter? The literature suggests those outside the educational institution are: peer pressure, parental pressure, lack of role models in the media, and a lack of information about consequences of career decisions (Beck, 1989).

Too often these obstacles are reinforced by educational institutions by not: providing complete and accurate career information, requiring counselors to discuss nontraditional options, establishing support systems for nontraditional students, requiring equitable treatment by teachers and administrators of females who select nontraditional options, conducting sex equity inservice training with staff, maintaining strict policy against sexual harassment, targeting recruitment or present special orientation programs for females in nontraditional career programs, reviewing and revising course materials to be inclusive of female and male students, and documenting and publicizing sex equity activities. The messages students receive through the educational system can shape lifetime work decisions. Enrollment data collected throughout the 80's based on male and female vocational choices, combined with the selection of college major by men and women, indicate occupational segregation by gender will continue well into the $21 \mathrm{st}$ century (Beck, 1989).

\section{Purpose and Objectives}

The purpose of this investigation was to identify and define deterrents to female enrollment in secondary agricultural education programs in Nebraska. The objectives of the study were to:

Identify critical considerations made by female students which influenced their decision of whether to enroll in agricultural education classes.

Compare and contrast parental, counselor and agricultural education instructor attitude toward enrollment of females in secondary agricultural education classes. 


\section{Procedure}

Population and Sample

The populations of this study included: (1) secondary agricultural instructors in Nebraska; (2) secondary counselors in high schools with agricultural education programs in Nebraska; (3) resident females who graduated from high schools offering agricultural education who were majoring in an area of study in the College of Agricultural Sciences and Natural Resources (CASNR). University of Nebraska-Lincoln and had not enrolled in agricultural classes at the high school level; and (4) parents of females currently enrolled in high school agricultural classes in Nebraska.

Table 1. Group, Population, Sample Size, Reliability, Response Rate, and Instrument Information

\begin{tabular}{ccccccc}
\hline & Popu- & Sample & \multicolumn{4}{c}{ Reli- } \\
Group & lation & Size & ability & Rate & \#Items & \#Pages \\
\hline$!$ & 132 & 40 & .89 & .95 & 56 & 6 \\
2 & 123 & 40 & .72 & .80 & 44 & 5 \\
3 & 37 & 37 & .95 & .81 & 45 & 5 \\
4 & $400-600$ & 160 & .73 & .40 & 33 & 3 \\
\hline
\end{tabular}

The population of secondary agriculture teachers was randomly sampled using a table of random numbers and a list of teachers from the Agricultural Education Department, UNL. The counselors sampled was determined by pairing them with the agricultural education teacher sample. In all instances, there was only one high school counselor in the school system. The college-age female population was identified by a confidential search of secondary transcripts found in files in the Dean's Office, CASNR. Because of the relatively small number $(\mathrm{N}=37)$, the total population was surveyed. The fourth population, parents, was identified by high school agricultural education instructors in the sample. Only one parent per female student responded and, in the case of two or more females in the agriculture program, only one response per family was requested.

\section{$\underline{\text { Instrumentation }}$}

Instrumentation for this study consisted of four different mailed questionnaires developed by the researchers. Questions on the instrument were derived following a review of literature and corresponded to the objectives of the study. Some similar questions were used in all or some of the instruments for comparison of responses. The instruments consisted of demographic questions and attitudinal questions related to courses, support networks, guidance, career awareness, facilities, others' perception of female enrollment in agricultural classes and school policy. A four point Likert scale (Istrongly agree to $4=$ strongly disagree) was used for response to attitudinal questions.

The instrument was reviewed for content validity by a panel of experts which consisted of teacher educators, educational psychologists, graduate students, counselors, agricultural education teachers, parents, and female college students.

The instrument was pilot tested for reliability using representatives of each of the four populations; these representatives were not included in the study sample.

\section{$\underline{\text { Data Collection }}$}


A questionnaire package was mailed containing the coded survey, cover letter and stamped return envelope. Initial follow-up of nonrespondents was a phone call to the agricultural education instructors, secondary counselors and female college students after two weeks. A phone call was made to instructors who contacted parents who had not returned the instrument. A second completed package was mailed to those who had misplaced or not received the first package. N onresponse error was controlled by comparing early to late respondents, which yielded no significant differences.

\section{Findings}

When reviewing the data regarding critical considerations made by college females, and the degree to which those considerations influenced their decision to not enroll in agricultural education courses, statements were categorized according to their source of influence. Those categories were (1) support networks (i.e. other females in the courses or encouragement provided by the instructor), (2) guidance and career awareness, (3) the agricultural education instructor, (4) agricultural education courses and facilities, and (5) other perceptions. In these categories it was observed that no considerations were identified by the respondents as strongly agreeing (1.5 rating or lower on a 4 point Likert Scale) to their influence. But they did agree to a lesser extent (score of 1.5 to 2.5) on the influence the considerations made on their decision to not enroll in agricultural education courses (Table 2). Females surveyed in this study disagreed (score of 2.6 to 4.0) that twelve of the twenty-nine considerations influenced their decision to not enroll in agricultural education courses.

Table 2. Degrees to Which Considerations Influenced Females' Decision to Not Enroll in Secondary Agricultural Education Courses.

Item (Influence Category) Mean SD Range Kurtosis $(\mathrm{N}=30)$

A lack of career information explaining opportunities for females in the agricultural industry (Guidance and career awareness)

$\begin{array}{llll}1.67 & .63 & 2 & -.82\end{array}$

A lack of career information explaining general employment opportunities in agriculture. (Guidance and career awareness)

$\begin{array}{lll}1.86 & .76 \quad 2\end{array}$

Counseling services did not provide an awareness of nontraditional employment and career opportunities available for students (i.e. males in nursing, females in construction, etc.). (Guidance and career awareness)

A lack of an existing supportive network for your participation in agricultural education courses (i.e. other females in the courses or encouragement provided by the instructor ) (Support networks)

The school counselor provided no guidance about the high school agricultural education program. (Guidance and career awareness)

$\begin{array}{llll}2.00 & .76 & 2 & -1.18\end{array}$

Agricultural education course content was based on a year--long program (Ag I, II, III \& IV), induding many different topics which was not responsive to your specific interest in agriculture. (Agricultural education courses and facilities) $2.33 \quad .76 \quad 3$

Note. Mean calculated from a scale of 1=Strongly Agree to 4= Strongly Disagree. Disagree herein was defined as 2.6-4.0. 
Table 2 continued.

\begin{tabular}{l} 
Item (Influence Category) \\
\hline Agricultural education courses were not easily \\
scheduled. (Agricultural education courses and
\end{tabular}

facilities)

2.44

Mean

SD Range Kurtosis

$(\mathrm{N}=30)$

You perceived that agricultural education course content was not relevant to current and future employment opportunities in the agricultural industry. (Agricultural education courses and facilities)

A lack of a successful female role model in the agricultural career in which you were interested. Support network)

$\begin{array}{llll}2.56 & 1.09 & 3 & -1.21\end{array}$

The instructor of agricultural education provided no guidance about the high school agricultural education program. (Agricultural education instructor)

Your peer group did not support your enrolling in agricultural education. (Support network)

You would not have received equal performance expectations compared to male students in agricultural education (Other perceptions)

Course titles and descriptions of agricultural education classes did not accurately describe course content using gender-neutral language (Agricultural education courses and facilities)

$\begin{array}{rrrr}2.64 & .95 & 2 & -.79 \\ 2.69 & 1.05 & \mathbf{3} & .89\end{array}$

$\begin{array}{llll}2.14 & .90 & 3 & -.74\end{array}$

Males already enrolled in agricultural education did

$\begin{array}{llll}2.77 & .61 & 2 & -.29\end{array}$

not see you as a sincere agricultural education student (Other perceptions)

$\begin{array}{llll}2.78 & .97 & 3 & -.79\end{array}$

The agricultural education classroom setting did not provide a comfortable gender-neutral atmosphere (i.e. colors, furniture, photographs, reading literature, etc.) (Agricultural education courses and facilities

Recruitment and/or special orientation programs targeted at females would not have encouraged you to enroll in agricultural education. (Guidance and career awareness)

You perceived that there was not an equal opportunity (gender bias) to participate in FFA activities. (Other perceptions)

A "close" female friend did not support your enrollment in agricultural education. (Support networks)

Protective clothing required of laboratory activities in agricultural classes was of gender-biased design. (Agricultural education courses and facilities)

The agricultural education instructor lacked professional appearance and/or conduct. (Agricultural education instructor)

Non-specific discouragement provided by the high school guidance counselor regarding enrollment in agricultural education (i.e. "Why to you want to enroll?") (Guidance and career awareness) 


\begin{tabular}{|c|c|c|c|c|}
\hline Item (Influence Category) & $\begin{array}{l}\text { Mean } \\
(\mathrm{N}=30) \\
\end{array}$ & $\mathrm{SD}$ & Range & Kurtosis \\
\hline $\begin{array}{l}\text { Your mother did not support your decision to enroll } \\
\text { (Support networks) }\end{array}$ & 3.24 & .83 & 3 & .63 \\
\hline $\begin{array}{l}\text { Dressing and/or restrooms in the agricultural } \\
\text { education facility did not provide privacy and } \\
\text { convenience. (Agricultural education courses } \\
\text { and facilities) }\end{array}$ & 3.24 & .66 & 2 & -.51 \\
\hline $\begin{array}{l}\text { Female Enrollment in agricultural education was } \\
\text { not accepted by other high school faculty in } \\
\text { your home high school (Other perceptions) }\end{array}$ & 3.25 & .75 & 3 & 1.57 \\
\hline $\begin{array}{l}\text { The school counselor advised you not to enroll } \\
\text { (Guidance and career awareness) }\end{array}$ & 3.26 & .81 & 3 & 1.29 \\
\hline $\begin{array}{l}\text { Female enrollment in agricultural education classes } \\
\text { was not accepted by citizens in your home community } \\
\text { (Other perceptions) }\end{array}$ & 3.29 & .66 & 3 & 1.57 \\
\hline $\begin{array}{l}\text { Females already enrolled or having completed the } \\
\text { agricultural education course or program } \\
\text { influenced your decision (Support networks) }\end{array}$ & 3.35 & .71 & 2 & -.70 \\
\hline $\begin{array}{l}\text { Your father did not support your decision to enroll } \\
\text { (Support networks) }\end{array}$ & 3.42 & .65 & 2 & -.42 \\
\hline $\begin{array}{l}\text { The instructor of agricultural education advised } \\
\text { vou not to enroll. (Agricultural education } \\
\text { instructor) }\end{array}$ & 3.64 & & & 1.80 \\
\hline
\end{tabular}

Upon comparing the perception of instructors, counselors, and parents to those considerations identified by females as influencing their decision to not enroll in secondary agricultural education, the following items were statistically significant:

A lack of career information explaining career opportunities for females in the agricultural industry.

Counseling services did not provide an awareness of nontraditional employment and career opportunities available for all students.

A lack of existing supportive network for participation in agricultural education courses.

On all three items instructors agreed to their significance in the promotion of female enrollment. In contrast to student opinion, counselors and parents felt students were being provided career awareness about the agricultural industry, and awareness was available to all students regarding nontraditional employment and career opportunities. All groups agreed with students that enrollment of females would increase if support systems were established.

Another significant difference existed between females who had or had not participated in a junior high exploratory program in agricultural education. Those not participating in a junior high program (93\%) agreed (2.20) their high school counselor did not provide guidance about the high school agricultural education program, and those who did (7\%) disagreed (3.50).

\section{Conclusions and Recommendations}

The following conclusions were drawn from the findings of this study. 
Critical obstacles encountered by females in this study within the educational institution when deciding whether to enroll in agricultural education classes were:

A lack of career information explaining both tradition and nontraditional employment opportunities for females.

A lack of counseling services providing awareness of nontraditional employment and career opportunities, and, specifically, guidance regarding their high school agricultural education program.

A lack of an existing supportive network for participation in agricultural education courses.

An agricultural education program delivery format not responsive to their needs.

Difficulty in scheduling agricultural education classes.

These conclusions are consistent with the literature and may be a result of the cultural bias demand side theory advanced by Lillydahl that career information, counseling and programming are either consciously or unconsciously influenced by the perception of "gender appropriate" occupational roles. Another consideration in regard to the lack of information may be as the literature suggests current career information fails to focus upon the consequences of nontraditional decisions, and these choices require too great of risk investment without sufficient assurances.

Obstacles encountered by females in this study outside of the education institution such as peer pressure, parental pressure, and lack of successful role models were less critical than those within the institution. This is not consistent with the related literature in the area. It may be, in part, due to the unique nature of the population (no secondary agricultural education yet declared a college major in agriculture) possessing a preference toward independent decision making.

Parents and counselors included in this study both reported that females were provided adequate awareness of career opportunities in agriculture. In stark contrast, adequate awareness of career opportunities in agriculture was the most critical obstacle for the females involved in the study. Counselors and parents are unaware of the critical considerations needed to be addressed in nontratidional career decisions being made by this population.

In support of previous literature findings, all groups included in this study (counselors, instructors, parents, and students) agreed female enrollment would increase if support systems were established.

Ninety-three percent of the females responding to this study had not participated in a junior high exploratory program in agricultural education.

Facilities were not a major deterrent to enrollment.

From the conclusions, the following recommendations were made:

Both formal research and informal investigation should be conducted to clarify critical career information and its delivery required by students when considering both traditional and nontraditional career opportunities. Such research and 
investigation should consider identifying the consequences of career decisions, the role of support groups, and the review and revision of course work based on nondiscriminatory programming.

Continued emphasis should be placed upon equity inservice education within the entire educational community in order to sensitize individuals to subtle role stereotyping embedded in cultural bias.

State leadership in education should provide inservice education to secondary educators on the theory and establishment of student support networks to facilitate nontraditional change.

Additional literature review and necessary research should be conducted to explore and identify the psychological considerations impacting individuals confronted with culturally nontraditional choices.

Follow-up research should e conducted with a male audience paralleling the educational background of the female audience surveyed in this research to compare considerations influencing their decision to not enroll to determine if considerations are generalizable beyond gender.

Secondary schools should be encouraged to re-evaluate the purpose and content of present and future junior high career exploratory programs to address more "global" career decisions such as nontraditional interests instead of total focus on technical content.

To better assure perceived relevancy by students to employment opportunities secondary agricultural education curriculum should be "student driven" instead of "program driven".

\section{References}

Beck, J. (1989). on Step. A Seven Step Process for Increasing the Enrollment of Women a $\mathrm{n} \mathrm{d}^{\circ}$ Girls in Non-traditional Programs. Washington, D. C.: Wider Opportunities for Women.

Cohen, J. (1977). Statistical power analysis for the behavioral sciences (2nd ed.). New York: Academic Press.

Committee on Agricultural Education in Secondary Schools, Board of Agriculture, National Research Council (1988). Understanding aericulture--new directions for education. Washington, D. C.: National Academy Press.

Coulter, K. J., Stanton, M. and Goecher, A. S. (1986). Employment opportunities for college in the food and agricultural sciences. Washington, D. C.: USDA, Higher Education Programs.

Giese, E. H. (1980). You can see the cat walking: A report on the findings of the Michigan Project on Equal Education Rights (PEER). Milford, Michigan: PEER.

Heifetz, R. (1991). A new look at leadership styles. Phi Kappa Phi Journal, 71(1), 1820 . 
Kotrilik. J. W. and Harrison, B. C. (1987). Factors related to the career decisions of seniors who have taken vocational agriculture. The Journal of the American Association of Teacher Educators in Aericulture, 28 (4), 50-56.

Krueger, D. E. and Riesenberg, L. E. (1991). Careers in agriculture as perceived by high school juniors and seniors. Proceedines of the National Aericulture Education Research Meeting. Los Angeles, California.

Lillydahl, J. J. (1986). Women and traditionally male blue collar jobs. Work and Occupations, $13(3), 303-323$.

Orthel, G. R., Sorensen, J. L., Lierman, S. R., and Riesenberg, L. E. (1989). High school students' perceptions of agriculture and careers in agriculture. Proceedines of the 16th National Agricultural Education Research Meeting. Orlando, Florida.

Sproles, E. K. (1986). Perceptions by nontraditional and traditional agricultural students toward their high school preparation and work barriers. Journal of the American Association of Teacher Educators in Aericulture, 28(2), 18-24.

Tannen, D. (1990). You Just Don't Understand:Women and Men in Conversation. New York: Ballentine Books. 